\title{
0 dokumencie z roku 1358 raz jeszcze
}

\author{
Henryk Rutkowski
}

Na wstępie chcę wyjaśnić, dlaczego w ciągu paru lat piszę w roczniku „Studia Geohistorica" na ten sam temat już po raz trzeci: najpierw był artykuł ${ }^{1}$, następnie polemika z Elżbietą Kowalczyk-Heyman², a teraz reakcja na tekst Przemysława Sianki ${ }^{3}$. Zaznaczam jednak, że Autor ten, pisząc swój tekst, nie mógł jeszcze znać wspomnianej polemiki i odnosił się wyłącznie do mojego artykułu.

Powodem, dla którego czuję się zmuszony do zabrania głosu, są przede wszystkim dwa miejsca z omawianej publikacji. W jednym Przemysław Sianko zarzuca mi wprost popełnienie kardynalnego błędu warsztatowego, ponieważ nie zauważyłem, że opinia Franciszka Sikory (na którą się powołuję) nie zaprzecza, jakoby dokument opatrzony rokiem 1358 mógł powstać w pierwszej połowie XV w. (s. 14, przyp. 10). W drugim Autor stwierdza zaś, że „dość nieporadnie” odsunąłem „dwa istotne zagadnienia świadczące o nieautentyczności dokumentu" (s. 33, przyp. 67). W przytoczonych zarzutach, które uznaję za nieuzasadnione (o czym niżej), dostrzegam przekonanie Autora, że negatywne oceny należy wyrażać bez owijania w bawełnę. Postaram się więc dostosować do tego stylu.

Przedmiotem dyskusji jest dokument księcia litewskiego Kiejstuta Giedyminowicza wystawiony 14 sierpnia $1358 \mathrm{r}$.

\footnotetext{
${ }^{1}$ H. Rutkowski, Granica mazowiecko-litewska między Wizną a Grodnem z 1358 r., ,Studia Geohistorica”, 5, 2017, s. 140-155.

${ }^{2}$ E. Kowalczyk-Heyman, 0 mazowiecko-litewskiej ugodzie granicznej z $1358 \mathrm{r}$. (gtos w dyskusii), „Studia Geohistorica”, 7, 2019, s. 213-226; H. Rutkowski, Odpowiedź na krytykę artykułu o granicy z 1358 r., „Studia Geohistorica”, 7, 2019, s. 227-233.

${ }^{3}$ P. Sianko, Rozgraniczenie mazowiecko-litewskie z 1358 r. - nowe spojizenie, W: Granice i pogranicza, red. P. Guzowski, M. Liedke, W. Walczak, Białystok 2019, s. 11-46. Odesłania do konkretnych stron tego artykułu umieszczam w tekście w nawiasach.
}

w Grodnie. Aktem tym Kiejstut zawiera z księciem mazowieckim Siemowitem III układ, który ustala granicę między Mazowszem a Litwą na podstawie tego, co $\mathrm{w}$ terenie postanowili pełnomocnicy obu stron ${ }^{4}$.

W celu dokładnego przedstawienia mojego stanowiska będę powtarzał argumenty $\mathrm{z}$ dwóch poprzednich publikacjí. W historiografii nie kwestionowano autentyczności omawianego dokumentu aż do $2000 \mathrm{r}$. Irena Sułkowska-Kuraś i Stanisław Kuraś ogłosili wtedy, że to uznawane za oryginał źródło pochodzi z pierwszej połowy $\mathrm{XV}$ w., a zatem jest falsyfikatem. Stwierdzenia, że dokument nie mógł powstać w 1358 r., dokonali jednak wyłącznie na podstawie analizy pisma. Gdyby potraktować ich twierdzenie ściśle i uwzględnić transumpt z 1434 r., należałoby umieścić sporządzenie rękopisu między latami 1401 i 1434. Wskazanie krótkiego zakresu czasu, w którym mogło powstać jakieś średniowieczne źródło, jedynie na podstawie cech pisma należy ocenić jako niepewne (wątpliwości mogłoby rozwiązać tylko rozpoznanie ręki pisarza znanego z innych tekstów). Mimo to autor pierwszego komentarza do edycji Kurasiów, Kazimierz Pacuski, przyjął ich tezę jako niebudzącą wątpliwości. Zająwszy się treścią dokumentu, słusznie zauważył, że wymienione w nim osoby odpowiadają podanej dacie. W konsekwencji uznał, że w 1358 r. doszło do rozgraniczenia mazowiecko-litewskiego, które zostało potwierdzone na zjeździe książąt i dygnitarzy obu stron. Po zjeździe tym pozostała w kancelarii mazowieckiej krótka zapiska

\footnotetext{
${ }^{4}$ Nowy kodeks dyplomatyczny Mazowsza [dalej: NKDM], cz. 3, wyd. I. Sułkowska-Kuraś, S. Kuraś, wsp. J. Piętka, Warszawa 2000, s. 30-32, nr 24. Zob. też: H. Rutkowski, Granica, s. 144-146.

${ }^{5}$ Tamże, s. 140-142; H. Rutkowski, Odpowiedź, s. 227-228.
} 
opatrzona datą roczną i zawierająca imiona uczestników. To na niej według Pacuskiego oparto później podrobiony dokument przypisany Kiejstutowi ${ }^{6}$.

Jak podałem w wymienionym artykule, dwaj znawcy paleografii, Franciszek Sikora i Aleh Lickiewicz, dokonali niezależnie od siebie sprawdzenia rękopisu i stwierdzili, że jest to dokument autentyczny. $\mathrm{Z}$ informacji przekazanych przez Sikorę wynika, że wydawcy zajęli się tym źródłem nie dość starannie (o czym świadczą liczne niedokładności edycji) i nie dokonując dokładnej analizy paleograficznej, sformułowali błędną opinię. Do takiej oceny prowadzą też rozważania Lickiewicza. Skoro analiza specjalistów dopuszcza możliwość datowania pisma na rok 1358, sprawa jest wyjaśniona. Informacja, że tak samo można było pisać w pierwszej połowie XV w., nie ma żadnego znaczenia dla oceny autentyczności tego źródła, dlatego zarzut Przemysława Sianki, że pomijając tę informację, popełniłem kardynalny błąd, odrzucam jako sprzeczny z logiką.

Autor omawianego artykułu stara się udowodnić, że dokument jest falsyfikatem. Oczywiście ma prawo tak postępować, ale ja mam pewność, że postawił przed sobą cel nieosiągalny. Konieczne byłyby tu argumenty niepodważalne, a takich nie dostrzegam.

Spośród rzekomych świadectw nieautentyczności dokumentu na pierwszym miejscu wymieniam brak upoważnienia Siemowita III przez Kazimierza Wielkiego, na to bowiem zwrócił uwagę już Pacuski (s. 14). Moim zdaniem nie ma to znaczenia, ponieważ nie chodziło o granicę Królestwa Polskiego, ale Mazowsza, a lennik Kazimierza Siemowit miał w owym roku pełnię władzy w ziemi wiskiej. Zobowiązanie lenne księcia zakazywało odstąpienia od króla, a w szczególności przejścia na

${ }^{6}$ K. Pacuski, Uzupetnienia i sprostowania do "Nowego kodeksu dyplomatycznego Mazowsza”, część III: „Dokumenty z lat 1356-1381”, ,Studia Źródłoznawcze", 40, 2002, s. 173-174. stronę Litwy, lecz w tym przypadku nic takiego nie miało się zdarzyć ${ }^{7}$.

Przemysław Sianko pisze, że skoro wielkim księciem litewskim był Olgierd, to mimo bardzo silnej pozycji, jaką zajmował w państwie jego brat Kiejstut, i powołania się $\mathrm{w}$ dokumencie na zgodę innych książąt nie Kiejstut, lecz Olgierd „wraz z innymi książętami litewskimi jako świadkami powinien być wystawcą dokumentu normującego stosunki graniczne z sąsiednim państwem” (s. 15). Przytoczone zdanie wygląda tak, jakby sytuacja ze średniowiecza oceniana była na podstawie nowoczesnych norm prawa międzynarodowego. Dokument nie dotyczył sporu dwóch państw o przynależność jakiegoś terytorium, a do zawarcia ugody doprowadziły „waśnie w przedmiocie pewnych szkód ponoszonych przez naszą ziemię Litwę i tegoż księcia Siemowita ziemię mazowiecką, a właściwie z powodu jeszcze nieustalonych i nieoznaczonych granic"8. Cytowany przez Autora w innym miejscu akt zawarcia pokoju między Polską a Litwą w 1366 r. (s. 33-34) wymienia ziemie i włości, które mają należeć do każdej ze stron, a ich granice traktuje jako ustalone9. W stosunkach między Mazowszem a Litwą w 1358 r. sprawa była inna, chodziło bowiem o delimitację, która zapobiegłaby dalszym konfliktom w wymiarze lokalnym.

W innym miejscu Autor pisze: „Poza tym wiadomo, że w 1358 r. księstwo grodzieńskie znajdowało się pod władzą nie Kiejstuta, ale księcia Patryka. Dawniejsza historiografia właśnie na podstawie omawianego tu aktu uznawała, że książę Patryk był synem Kiejstuta, co w naturalny sposób sprawiało, że to ten ostatni miał

\footnotetext{
7 Trzy dokumenty z 27 grudnia 1355 r.: NKDM, cz. 2, wyd. I. Sułkowska-Kuraś, S. Kuraś, Wrocław 1989, s. 350-355, nr 338-340; H. Rutkowski, Granica, s. 146.

${ }^{8}$ NKDM, cz. 3, s. 30, nr 24; H. Rutkowski, Granica, s. 145.

${ }^{9}$ A. Czuczyński, Traktat książąt litewskich z Kazimierzem Wielkim z roku 1366, „Kwartalnik Historyczny”, 4, 1890, s. 513-515; G. Błaszczyk, Dzieje stosunków polsko-litewskich od czasów najdawniejszych do wspótczesności, t. 1: Trudne początki, Poznań 1998, s. 159-161.
} 
być odpowiedzialny za stosunki polityczne z sąsiadami. Badania Jana Tęgowskiego dowodzą jednak, że ojcem Patryka był Narymunt, najstarszy brat Kiejstuta” (s. 15). Nie zgadzam się z tym poglądem. Należy zauważyć, że Przemysław Sianko zupełnie pominął pracę Jarosława Nikodema, który polemizując z Tęgowskim, przekonująco wykazał, że Patryk (a właściwie Patirg) był synem Kiejstuta. Ojciec wydzielił mu ze swej dzielnicy trockiej okręg grodzieński, ale zachował prawa zwierzchnie i dlatego tytułował się panem Grodna ${ }^{10}$. W 1358 r. Patryk stał na czele grupy litewskiej w komisji, która przeprowadziła rozgraniczenie ${ }^{11}$.

Przemysław Sianko wypowiada się z nieukrywaną pewnością, że oryginalny dokument Kiejstuta nie mógł być napisany po łacinie, ale "musiał być pisany po rusku” (s. 14, przyp. 10). Stąd też wziął się wspomniany zarzut wobec mojej następującej wypowiedzi, ocenionej jako „dość nieporadna” (s. 33, przyp. 67): „Tekst dokumentu litewskiego, choć mógłby być spisany po rusku, ze względu na odbiorcę jest łaciński, a wyszedł spod ręki kogoś, kto dobrze znał język polski, na co wskazuje pisownia nazw geograficznych"12. Chcę zatem dodać teraz do tego kolejne uwagi. W ówczesnych konfliktach mazowiecko-litewskich strona agresywną byli Litwini - to oni najeżdżali na Mazowsze. Można w związku z tym przypuszczać, że bardziej zainteresowany ugodą był książę mazowiecki, który chciał zapewnić poddanym bezpieczeństwo na własnym terytorium. Dokument został napisany w Grodnie, prawdopodobnie przez pisarza, który przybył z dygnitarzami mazowieckimi ${ }^{13}$. Moim zdaniem miał

\footnotetext{
${ }^{10}$ J. Nikodem, Patirg (Patryk?) Kiejstutowic czy Patryk Narymuntowic? Próba identyfikacji księcia władającego Grodnem do 1365 roku, „Genealogia”, 13, 2001, s. 133-150.

${ }^{11}$ H. Rutkowski, Granica, s. 145-146.

${ }^{12}$ Tamże, s. 145.

${ }^{13}$ Należy przypomnieć, że w dyplomatyce występuje termin dyktat odbiorcy. Istnieją 63 znane dokumenty Siemowita III, w tym 18 zachowanych w oryginale. J. Grabowski, Kancelarie i dokumenty ksiazząt mazowieckich w latach 1341-1381. Ośrodki zarządzania i kultury, Warszawa 1999, s. 141-262.
}

on charakter zobowiązania Litwy, że nie będzie naruszać ustalonej wówczas granicy, co uwierzytelnił swoją pieczęcią książę Kiejstut.

W tym miejscu należy powołać się na dokument wystawiony przez Siemowita IV Januszowi I w 1401 r., gdy pierwszy z braci oddał drugiemu w zastaw ziemię wiską. W źródle tym zapisano, że na czas trwania zastawu Siemowit przekazał Januszowi w celu obrony granic - uwierzytelniony dokument o rozgraniczeniu ziem: grodzieńskiej z jednej strony, a wiskiej i goniądzkiej z drugiej ${ }^{14}$. Nie mam wątpliwości, że został tu wymieniony dokument Kiejstuta. W 1401 r. miał on dowodzić, jak przebiegała granica państwowa uzgodniona w 1358 r. z Litwinami, którzy już jej nie przestrzegali i zajęli powiat goniądzki ${ }^{15}$.

Trzy występujące w dokumencie Kiejstuta jednostki terytorialne określone są tym samym słowem - districtus. Trzeba to przyjąć jako ogólne określenie okręgów, bez różnicowania ich na księstwo, ziemię i powiat. Przemysław Sianko zarzuca mi, że nie spróbowałem dociec, dlaczego twórca dokumentu „nie użył prawidłowych dla epoki nazw” (s. 15-17). Również teraz uchylam się od odpowiedzi na to pytanie. Zdaniem Autora wymienione w dokumencie Goniądz i Rajgród w 1358 r. jeszcze nie istniały (s. 16-17, 23). Zarówno do tych grodów, jak i do Targowiska oraz Popielowego Siedliska odnosi się sformułowanie: „miejscowości wymienione jako pograniczne, dowodnie powstałe dopiero w XV w." (s. 41). Skoro mowa o dowodach, to gdzie one są?

Ostatnim z rzekomych dowodów, że omawiany dokument jest falsyfikatem, ma być uwzględnienie $\mathrm{w}$ nim ziemi wiskiej mimo wyodrębnienia $\mathrm{z}$ niej okręgu

\footnotetext{
${ }^{14}$, „[... litteras nostras super limitationibus et limittibus ac graniciebus inter terras et dominia videlicet Grodnen[sem] ex una et Visnen[sem] ac Gonyandzen[sem] parte ex altera consignatas, factas et ordinatas eidem fratri nostro dedimus et ad defenssionem granicierum predictarum contulimus". Iura Masoviae terrestia, t. 1, oprac. J. Sawicki, Warszawa 1972, s. 89, nr 56. ${ }^{15}$ H. Rutkowski, Odpowiedź, s. 227-228.
} 
goniądzkiego. „W literaturze można znaleźć stwierdzenia, że ziemia wiska rozciągała się też na lewym brzegu Narwi [...]. Szersza analiza tego zagadnienia nakazuje przyjąć, że ziemia wiska nigdy nie rozciągała się na lewy brzeg Narwi - obszar ten stanowił część kasztelanii nowogrodzkiej, później zaś ziemi łomżyńskiej” (s. 17, przyp. 23). W cytowanym artykule napisałem, że odnośnie do roku 1358 pewna wydaje się przynależność do Wizny osiedli nad równoleżnikowym biegiem Narwi i nad Supraślą oraz terenu na południe od tych rzek ${ }^{16}$. Później uzasadniłem twierdzenie, że zmiana granic ziemi wiskiej (czyli zmniejszenie jej obszaru) dokonała się w 1379 r. $^{17}$

Po przedstawieniu rzekomych dowodów fałszerstwa Przemysław Sianko konkluduje: „Już więc tylko powyższa argumentacja nakazuje przyjąć, że »rozgraniczenie 1358 r.» to w rzeczywistości próba oszustwa, na dodatek bardzo nieudolna” (s. 18). Dalej zaś następuje ocena, że rozgraniczenie na północnym odcinku „nie miało większego sensu” - „Siemowit III powinien być bardziej zainteresowany unormowaniem południowo-wschodniej granicy mazowieckiej, która stykała się z litewską ziemią drohicką" (s. 18-19).

Dużą część omawianego artykułu zajmuje analiza opisu granicy przedstawionego w spornym dokumencie (s. 19-30). Widać tam m.in. różne rozumienie łacińskiego przyimka per w stosunku do rzek: w jednym miejscu w znaczeniu 'wzdłuż biegu rzeki' (s. 29-30), a w innym jako 'przecinając rzekę' (s. 24-25). Autor w ogóle nie odniósł się do faktu, że moje stanowisko odnośnie do przebiegu granicy wynika z faktu, że przetrwała ona aż do rozbiorów Rzeczypospolitej. Konsekwencją tej konstatacji jest zatem zastosowanie przeze mnie retrogresji ${ }^{18}$.

W końcowej części artykułu (s. 34-43) czytamy rozważania Autora, które mają wyjaśnić okoliczności i moment sporządzenia rzekomego falsyfikatu. Wskazany zakres czasowy jest krótki - koniec sierpnia lub początek września 1434 r. Ponieważ dokument Kiejstuta jest oryginałem z 1358 r., oceniam wzmiankowane dywagacje tak, jakby stanowiły odpowiedź na pytanie: Co by było, gdyby w pierwszej połowie XV w. akt ten nie istniał? Moim zdaniem te pokrętne wywody są bliskie typu pisarstwa, który określa się jako historię alternatywną. Może mieć ona jakąś wartość poznawczą, ale nie ma charakteru naukowego.

Przemysław Sianko wydaje się żywić przekonanie, że odsłonił nieznaną historykom kartę ze średniowiecza. Moim zdaniem natomiast Jego tekst na pewno nie powinien ukazać się $\mathrm{w}$ zbiorze prac naukowych.

$\mathrm{Na}$ wstępie wyjaśniłem, dlaczego niniejsza polemika ma być ostra. Puentą niech będą słowa klasyka literatury francuskiej w znanym przekładzie polskiego pisarza: „Sam chciałeś, Grzegorzu Dyndało, sam chciałeś".

\footnotetext{
${ }^{16}$ Tenże, Granica, s. 145

${ }^{17}$ Tenże, Odpowiedź, s. 231-232.
}

\footnotetext{
${ }^{18}$ Tenże, Granica, s. 148; tenże, Odpowiedź, s. 228. Por. tenże, Metoda retrogresji w geografii historycznej Polski (wybrane zagadnienia), „Studia Geohistorica", 7, 2019, s. 146-162.
} 


\section{Bibliografia}

Błaszczyk G., Dzieje stosunków polsko-litewskich od czasów najdawniejszych do wspótczesności, t. 1: Trudne początki, Poznań 1998.

Czuczyński A., Traktat książąt litewskich z Kazimierzem Wielkim z roku 1366, „Kwartalnik Historyczny”, 4, 1890 .

Grabowski J., Kancelarie i dokumenty książat mazowieckich w latach 1341-1381. Ośrodki zarzadzania i kultury, Warszawa 1999.

Granice i pogranicza, red. P. Guzowski, M. Liedke, W. Walczak, Białystok 2019.

Iura Masoviae terrestia, t. 1, oprac. J. Sawicki, Warszawa 1972.

Kowalczyk-Heyman E., O mazowiecko-litewskiej ugodzie granicznej z 1358 r. (gtos $w$ dyskusji), „Studia Geohistorica", 7, 2019.

Nikodem J., Patirg (Patryk?) Kiejstutowic czy Patryk Narymuntowic? Próba identyfkacji księcia wtadającego Grodnem do 1365 roku, „Genealogia”, 13, 2001.

Nowy kodeks dyplomatyczny Mazowsza, cz. 2, wyd. I. Sułkowska-Kuraś, S. Kuraś, Wrocław 1989.
Nowy kodeks dyplomatyczny Mazowsza, cz. 3, wyd. I. Sułkowska-Kuraś, S. Kuraś, wsp. J. Piętka, Warszawa 2000.

Pacuski K., Uzupetnienia i sprostowania do „Nowego kodeksu dyplomatycznego Mazowsza”, częśc III: „Dokumenty z lat 1356-1381”, „Studia Źródłoznawcze”, 40, 2002.

Rutkowski H., Granica mazowiecko-litewska między Wizną a Grodnem z 1358 r., „Studia Geohistorica”, 5, 2017.

Rutkowski H., Metoda retrogresji w geografii historycznej Polski (wybrane zagadnienia), „Studia Geohistorica”, 7, 2019.

Rutkowski H., Odpowiedź na krytykę artykutu o granicy z 1358 r., „Studia Geohistorica”, 7, 2019.

Sianko P., Rozgraniczenie mazowiecko-litewskie z 1358 r. - nowe spojrzenie, w: Granice i pogranicza, red. P. Guzowski, M. Liedke, W. Walczak, Białystok 2019. 